\title{
MODEL PEMBELAJARAN DISCOVERY LEARNING UNTUK MENINGKATKAN KETERAMPILAN BERPIKIR KRITIS SISWA KELAS 5 SD
}

\author{
Rizky Aprilia Rakhmawati* \& Mawardi \\ Universitas Kristen Satya Wacana, Indonesia \\ *Corresponding Author: apriliarizky18@gmail.com
}

Article History
Received : April $29^{\text {th }}, 2021$
Revised : May $15^{\text {th }}, 2021$
Accepted : May $25^{\text {th }}, 2021$
Published : May $31^{\text {th }}, 2021$

\begin{abstract}
Abstrak: Latar belakang penelitian ini adalah proses pembelajaran siswa kelas 5 SDN Sidorejo Lor 06 memperlihatkan bahwa kemampuan siswa untuk berpikir kritis saat aktivitas belajar mengajar masih rendah dan juga cenderung pasif. Penelitian ini adalah Penelitian Tindakan Kelas (Classroom Action Research) yang mempunyai tujuan memperbaiki kapabilitas berpikir kritis murid kelas 5 SD N Sidorejo Lor 06 Salatiga dengan memanfaatkan metode belajar Discovery Learning. Subjek penelitian ini adalah siswa kelas 5 dengan jumlah 19 orang. Teknik perolehan data memanfaatkan lembar observasi, catatan kaki, serta pengukuran kemampuan pemikiran kritis siswa. Teknik analisis data yang dimanfaatkan pada riset ini yakni analisa data kuantatif yang dianalisis memanfaatkan analisis deskriptif. Hasil observasi pra siklus menunjukkan bahwa terdapat $15,79 \%$ siswa termasuk kategori berpikir kritis tinggi, 26,32\% siswa tergolong dalam kelompok siswa berpikir kritis sedang, 31,58\% siswa tergolong dalam kelompok siswa berpikir kritis rendah dan $26,32 \%$ siswa tergolong dalam kelompok berpikir kritis sangat rendah. Setelah dilakukan tindakan menggunakan metode pembelajaran Discovery Learning terjadi peningkatan pada keterampilan berpikir kritis siswa pada siklus I menjadi 26,32\% pada kategori sangat tinggi, $31,58 \%$ pada kategori tinggi, 15,79\% kategori sedang, dan 26,32\% pada kategori rendah. Kemudian pada siklus II terjadi peningkatan menjadi $42,10 \%$ kategori sangat tinggi, 36,84\% kategori tinggi, dan 21,05\% kategori sedang. Kesimpulan dari penelitian ini adalah model pengajaran Discovery Learning dapat mengasah keterampilan berpikir kritis siswa kelas 5 di SD Negeri Sidorejo Lor 06 Salatiga yang ditunjukkan dengan meningkatnya hasil penelitian dari pra siklus, siklus I dan siklus II.
\end{abstract}

Kata Kunci: Discovery Learning; Keterampilan Berpikir Kritis.

\section{PENDAHULUAN}

Pembelajaran tematik merupakan kegiatan belajar yang berupa kesatuan dan mencakup beberapa aspek pengetahuan sehingga mampu mengembangkan ilmu, perilaku, serta keterampilan siswa dengan optimal. Pembelajaran ini memanfaatkan topik-topik yang sering ditemukan di kehidupan keseharian muris sehingga pembelajaran menjadi lebih berarti karena murid bisa mengidentifikasi dan memahami materi pelajarannya. Mawardi (2014: 109) menyatakan, pembelajaran tematik terpadu bertujuan untuk mempermudah siswa untuk mengerti serta memahami lebih dalam konsep pelajaran yang ada dalam tema serta mampu meningkatkan gairah belajar siswa karena materi yang dibahas adalah materi aplikatif (kontekstual) serta bermanfaat untuk murid. Kemendikbud (2013: 192-193) menyatakan bahwa sistem belajar tematik integratif/ terpadu memanfaatkan topik sebagai menggabung aktivitas belajar dengan mencampurkan beberapa bidang studi sekaligus dalam satu pertemuan, sehingga peserta didik diharapkan mendapat pembelajaran yang lebih menarik karena murid diajak untuk memahami suatu konsep dengan pengalaman langsung kemudian mampu menghubungkannya dengan konsep lain yang telah dipahami.

Berdasarkan opini tersebut, ditarik kesimpulan bahwa metode tematik adalah strategi dalam kegiatan belajar yang dirancang untuk murid sekolah dasar. Metode tematik terintegrasi merupakan metode yang disusun menurut topik tertentu. Dalam penjabarannya, tema tersebut diambil dari berbagai bidang studi. Metode tematik memberikan kebebasan serta pemahaman yang lebih mendam akan pengaplikasian suatu materi, memberikan banyak kesempatan kepada murid untuk menumbuhkan dinamika dalam pembelajaran. Sesuai dengan tahapan pertumbuhan siswa, tipe belajar siswa, konsep serta makna pembelajaran, 
maka aktivitas belajar untuk murid sekolah dasar disarankan memanfaatkan metode tematik.

Saat ini hampir seluruh negara di dunia berada dalam masa pandemi Covid-19 yang mepengaruhi dunia pendidikan selain tentunya dunia kesehatan. Dalam bidang Pendidikan kegiatan pembelajaran dilakukan secara daring (online). Kegiatan pembelajaran daring ini mengharuskan guru untuk menggunakan mengembangkan model pembelajaran yang menyenangkan karena pembelajaran dilakukan dari rumah dan tidak dipantau guru secara langsung. Kebijakan kegiatan belajar mengajar secara daring oleh sekolah dapat dijadikan sarana untuk mengasah keterampilan pembelajaran di abad 21 yakni kapabilitas berpikir kritis.

Kapabilitas untuk berpikir kritis dalam proses belajar-mengajar kurikulum 2013 wajib dimiliki siswa karena keterampilan ini sangat dibutuhkan saat aktivitas belajar di sekolah maupun rumah serta dalam hidup bermasyarakat. Keterampilan berpikir kritis penting untuk diasah lewat aktivitas belajar-mengajar, namun tidak seluruh kegiatan belajar dapat mengasah keterampilan berpikir kritis milik siswa. Aktivitas belajar yang dapat meningkatkan keterampilan berpikir kritis contohnya dengan diskusi, kebebasan berpendapat, memfasilitasi kerjasama untuk meninjau serta mengembangkan ilmu baru.

Menurut Fahruddin Faiz (2012: 3) keterampilan berpikir kritis adalah kapabilitas yang sangat penting dalam pekerjaan, hidup sehari-hari serta agar dapat berfungsi efektif dalam seluruh aspek kehidupan. Kelebihan yang diperoleh saat berpikir kritis yakni individu dapat menentukan validitas dari suatu konsep serta tidak menerima semua informasi tanpa berpikir panjang. Sedangkan menurut Jhonson (Eti Nurhayati, 2011: 67) berpikir kritis adalah aktivitas mental yang teratur dengan baik dan berfungsi untuk membantu pengambilan kebijakan guna menyelesaikan suatu persoalan dengan cara menganalisa serta mengartikan data yang diperolah dalam suatu aktivitas inkuiri ilmiah. Menurut pendapat Toni Hidayat, Mawardi \& Suhandi Astuti (2019: 4) berpikir kritis adalah kapabilitas untuk berpikir dalam tahap yang kompleks pada suatu teori atau persoalan yang selanjutnya dianalisis untuk mendapatkan informasi ilmiah dengan memanfaatkan metode Analisa dan evaluasi.

Menurut berbagai penjelasan tersebut, bisa ditarik kesimpulan bahwa berpikir kritis merupakan metode berpikir yang menggunakan nalar serta dapat dipahami berupa aktivitas pengaturan, analisa, serta peninjauan kembali data dengan tujuan utama untuk menemukan kesimpulan dari riset yang dilaksanakan. Datadata terkait bisa didapatkan dari pengalaman, nalar, komunikasi, maupun observasi.

Berdasarkan pendapat Eti Nurhayati (2011: individu yang bisa berpikir kritis yakni: (1) mempunyai konsep pemikiran tertentu yang dimanfaatkan untuk mencapai gagasannya; (2) mempunyai keinginan kuat untuk menemukan serta menyelesaikan persoalan; (3) mempunyai sikap skeptik yaitu tidak mudah menelan konsep tertentu kecuali kebenarannya sudah dibuktikan sendiri. Menyangkut hal tersebut, banyak ketentuan yang melandasi penilaian kapabilitas berpikir kritis karena sesuai yang telah dijelaskan sebelumnya bahwa untuk menilai kapabilitas berpikir kritis cukup sulit karena hal tersebut bersifat abstrak.

Hasil observasi awal oleh peneliti pada proses pembelajaran siswa kelas 5 SDN Sidorejo Lor 06 memperlihatkan bahwa kemampuan siswa untuk berpikir kritis saat aktivitas belajar mengajar masih rendah. Dalam aktivitas belajar siswa umumnya bersikap pasif akan pertanyaanpertanyaan yang diajukan oleh pengajar sehingga pembelajaran yang berlangsung menjadi monoton atau membosankan dan membuat keterampilan berpikir kritis siswa mejadi tidak terasah. Selain itu siswa tidak didorong untuk mencari sumber pembelajaran lain selain materi yang disampaikan guru sehingga kegiatan belajar mengajar yang berlangsung masih berpusat pada pendidik dan belum terfokus di murid. Kapabilitas untuk berpikir kritis siswa juga memberi pengaruh atas hasil belajarnya yang kurang baik. Muatan pelajaran IPA dapat mengasah keterampilan berpikir kritis siswa, dan sebaliknya hasil pembelajaran IPA yang rendah milik murid dapat ditingkatkan dengan berpikir kritis.

Pengaplikasian model pembelajaran Discovery Learning, siswa diharapkan dapat menuntaskan seluruh permasalahan yang ditemui di sekolah maupun di kehidupan sehari-hari. Aktivitas mengajar dengan menggunakan metode Discovery Learning membantu siswa untuk memahami konsep dengan memberikan materi yang berfokus pada kegiatan berpikir murid. Dengan demikian penulis mengharapkan melalui metode Discovery Learning dapat mengasah kapabilitas berpikir kritis siswa kelas V SD Negeri Sidorejo Lor 06 Salatiga.

Model pembelajaran merupakan suatu rancangan atau model yang dimanfaatkan untuk 
dijadikan acuan dalam menyusun pembelajaran berbentuk tutorial (Trianto, 2010:51). Model pembelajaran mengarah pada penelusuran metode yang akan dimanfaatkan, termasuk tujuan pembelajaran, tahapan aktivitas mengajar, serta lingkungan belajar dan pengaturan kelas menurut Kardi , S. dan Nur (dalam Trianto, 2010:52).

Model pembelajaran Discovery Learning berdasar atas konsep-konsep belajar yang membangun (Anyafulude, 2013: 2). Berdasarkan konsep konstruktivisme, belajar merupakan aktivitas yang dilakukan saat murid menemukan arti, dialog, wacana, serta pengalaman nyata dimana terdapat proses penggabungan antara pengetahuan yang diperoleh dengan pengalaman yang dialami (Rifa'i \& Anni, 2011: 199). Berdasarkan penjelasan tentang model pembelajaran Discovery Learning, bisa ditarik kesimpulan bahwa metode belajar Discovery Learning adalah model pembelajaran yang mengharuskan murid untuk berperan nyata dalam pembelajaran dengan mengidentifikasi/membangun pemahaman materi dari suatu permasalahan dan dapat menghubungkannya seturut dengan pengalaman atau pengetahuan yang telah didapat.

Berdasarkan penjabaran tersebut, maka penulis memiliki ketertarikan untuk melaksanakan riset mengenai "Model Pembelajaran Discovery Learning Untuk Meningkatkan Keterampilan Berpikir Kritis Siswa Kelas 5 SD”. Tujuan dari penelitian ini yakni guna mengembangkan langkah-langkah metode pengajaran Discovery Learning dalam rangka mengasah kapabilitas berpikir kritis siswa kelas 5 SD.

\section{METODE}

Jenis penelitian ini merupakan Penelitian Tindakan Kelas (Classroom Action Reasearch). Model penelitian tindakan yang dimanfaatkan yakni model Stringer, yang dikategorikan ke dalam 3 komponen yaitu Look, Think, and Act. Penelitian ini dilaksanakan pada murid kelas V di SD Negeri Sidorejo Lor 06 Salatiga semester II tahun ajaran 2020/2021. Jumlah siswa kelas V adalah 19 orang, 11 siswa perempuan dan 8 siswa laki-laki. PTK dilakukan pada tema 7 Peristiwa dalam Kehidupan subtema 2 Peristiwa Kebangsaan Seputar Proklamasi Kemerdekaan dengan muatan pelajaran IPA Perubahan Wujud Benda. Penelitian dilaksanakan dengan 2 siklus. Sebelum pelaksanaan peneliti melakukan observasi (look), kemudian peneliti merancang perilaku yang akan diambil untuk menemukan solusi dari persoalan yang di dapatkan dari hasil observasi (think), lalu melaksanakan tindakan (act) untuk pelaksanaan siklus 1. Setelah melaksanakan siklus 1, kemudian peneliti menganalisis hasil pelaksanaan tindakan siklus 1 (look), kemudian memikirkan langkah untuk perbaikan perilaku siklus 2 (think), selanjutnya pelaksanaan perilaku siklus 2 (act).

Variabel dalam riset ini terdiri dari dua variabel, yakni variabel tidak terikat serta variabel terikat. Variabel tidak terikat dalam studi ini adalah model pembelajaran Discovery Learning, sementara variabel terikatnya yakni kapabilitas berpikir kritis. Teknik perolehan data memanfaatkan lembar observasi dan penilaian kemampuan berpikir kritis siswa. Metode analisa data yang dimanfaatkan pada riset ini merupakan analia data kuantitatif yang dianalisis memanfaatkan analisa deskriptif.

\section{HASIL DAN PEMBAHASAN}

Sebelum menjabarkan hasil dan pembahasan penelitian ini, indikator kemampuan berpikir kritis siswa yang diambil dalam penelitian ini adalah: 1) mampu merumuskan pokok-pokok permasalahan; 2) mampu mengungkapkan fakta untuk menyelesaikan permasalahan; 3) mampu memilih pendapat yang sesuai dengan kenyataan; 4) mampu memberikan pendapat dari sudut pandang yang berbeda; dan 5) mampu menyelesaikan masalah yang timbul dari suatu pernyataan.

Data keterampilan berpikir kritis siswa dapat diklasifikasikan sesuai perolehan skor dari penghitungan skor indikator kemampuan berpikir kritis siswa yang kemudian dilasifikasikan dalam tabel di bawah ini.

Tabel 1. Klasifikasi Perolehan Skor Indikator Keterampilan Berpikir Kritis

\begin{tabular}{cll}
\hline No & \multicolumn{1}{c}{ Perolehan Skor } & \multicolumn{1}{c}{ Kategori } \\
\hline $\mathbf{1}$ & $86-100$ & Sangat Tinggi \\
\hline $\mathbf{2}$ & $71-85$ & Tinggi \\
\hline $\mathbf{3}$ & $56-70$ & Sedang \\
\hline $\mathbf{4}$ & $31-55$ & Rendah \\
\hline $\mathbf{5}$ & $01-30$ & Sangat Rendah \\
\hline
\end{tabular}

Kondisi awal untuk riset ini di dapatkan dari hasil observasi kapabilitas berpikir kritis siswa dari materi sebelumnya. Hasil observasinya memperlihatkan bahwa dari 19 
siswa ada $15,79 \%$ siswa yang dikategorikan ke golongan berpikir kritis tinggi, 26,32\% siswa yang dikategorikan dalam kategori berpikir kritis sedang, 31,58\% siswa tergolong dalam kategori berpikir kritis rendah dan $26,32 \%$ siswa tergolong dalam berpikir kritis sangat rendah. Tabel 2 berikut menjabarkan frekuensi kemampuan berpikir kritis siswa pada pra siklus, siklus I, dan siklus II.

Tabel 2. Frekuensi Kemampuan Berpikir Kritis Siswa Kelas 5 SD N Sidorejo Lor 06 Salatiga pada Pra Siklus, Siklus I, dan Siklus II

\begin{tabular}{lcccccc}
\hline \multirow{2}{*}{ Kategori } & \multicolumn{2}{c}{ Pra Siklus } & \multicolumn{2}{c}{ Siklus I } & \multicolumn{2}{c}{ Siklus II } \\
\cline { 2 - 7 } & Frekuensi & Presentase & Frekuensi & Presentase & Frekuensi & Presentase \\
\hline Sangat Tinggi & 0 & $0 \%$ & 5 & $26,32 \%$ & 8 & $42,10 \%$ \\
\hline Tinggi & 3 & $15,79 \%$ & 6 & $31,58 \%$ & 7 & $36,84 \%$ \\
\hline Sedang & 5 & $26,32 \%$ & 3 & $15,79 \%$ & 4 & $21,05 \%$ \\
\hline Rendah & 6 & $31,58 \%$ & 5 & $26,32 \%$ & 0 & $0 \%$ \\
\hline Sangat Rendah & 5 & $26,32 \%$ & 0 & $0 \%$ & 0 & $0 \%$ \\
\hline
\end{tabular}

Dari tabel 1 di atas, memperlihatkan peningkatan hasil kemampuan berpikir kritis siswa dari data pra siklus kemudian melakukan tindakan pada siklus I adalah sebesar $63,16 \%$. Setelah tindakan pada siklus I adalah sebesar $26,32 \%$ pada kategori sangat tinggi, $31,58 \%$ pada kategori tinggi, $15,79 \%$ kategori sedang, dan $26,32 \%$ kategori rendah. Setelah tindakan pada siklus I peneliti melanjutkan dengan tindakan siklus II yang menunjukkan peningkatan presentase kemampuan berpikir kritis sebesar $42,10 \%$ pada kategori sangat tinggi, 36,84\% kategori tinggi, dan $21,05 \%$ pada kategori sedang. Selanjutnya setelah dilaksanakan observasi pada proses pembelajaran pra siklus, siklus I dan siklus II, didapatkan data peningkatan hasil riset yang ditunjukkan pada grafik berikut.

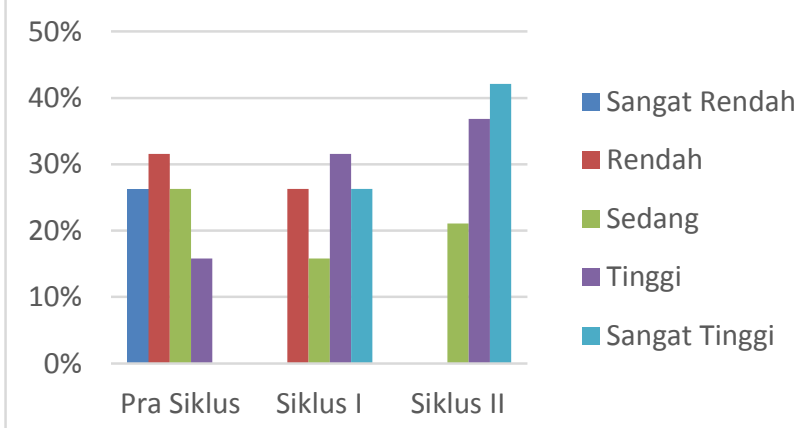

Gambar 1. Presentase Peningkatan Kemampuan Berpikir Kritis Siswa Kelas 5 SD Negeri Sidorejo Lor 06 Salatiga

Menurut ilustrasi grafik di atas, penelitian yang dilakukan menunjukkan hasil presentase kapabilitas berpikir kritis siswa kelas 5 yang membaik dari kondisi awal (pra siklus), siklus I dan siklus II. Kenaikan pada keterampilan berpikir kritis siswa ini ditunjukkan dengan peningkatan sebesar $15,78 \%$ pada kategori sangat tinggi dari $26,32 \%$ pada siklus I menjadi $42,10 \%$ pada siklus II, sedangkan pada kelompok tinggi naik 5,26\% dari 31,58\% siklus I menjadi 36,84\% pada siklus II dan kategori sedang naik 5,26\% dari $15,79 \%$ siklus I menjadi $21,05 \%$ pada siklus II. Dengan hasil yang diperoleh ini maka menyatakan bahwa pemanfaatan model pembelajaran Discovery Learning mampu mengasah kapabilitas berpikir kritis siswa kelas 5 pada muatan pelajaran IPA dengan materi perubahan wujud benda.

Penelitian yang telah dilakukan ini menunjukkan peningkatan dan dapat terlaksana dengan baik karena dalam pembelajaran Discovery Learning dilaksanakan dengan langkah-langkah (Syah dalam Kemendikbud, 2013: 5):

a. Stimulation

(Stimulasi/Pemberian

Rangsangan): aktivitas awal yang dilaksanakan dengan memberi persoalan yang dapat memancing keingintahuan murid untuk melaksanakan penelitian lebih lanjut terkait persoalan tersebut. Pada penelitian ini proses pemberian rangsangan dilakukan dengan kegiatan apersepsi untuk membangun pengetahuan awal anak tentang praktik pembelajaran yang akan berlangsung.

b. Problem Statement (Pernyataan/Identifikasi Masalah): memfasilitasi murid untuk menganalisis persoalan-persoalan yang didapatkan dari tahap sebelumnya. Pemberian kesempatan untuk menganalisis persoalan yang didapatkan ini adalah metode yang bertujuan untuk membiasakan murid 
mengidentifikasi persoalan. Setelah melakukan stimulasi tahap selanjutnya adalah memberikan suatu persoalan untuk memecahkan masalah dalam pembelajaran yang berlangsung.

c. Data Collection (Pengumpulan Data): hipotesa yang sudah dikembangkan dapat diuji validitasnya melalui aktivitas eksplorasi yang dilaksanakan oleh murid di bawah bimbingan pengajar. Pengujian dilaksanakan dengan mencari informasi atau data yang berkaitan lewat jelajah pustaka, percobaan, observasi, maupun tanya-jawab dengan narasumber guna membuktikan kebenaran teori sementara. Proses pengumpulan data dibimbing oleh guru dengan melakukan percobaan sehingga dapat membuktikan teori sementara yang telah disusun.

d. Data Processing (Pengolahan Data): informasi yang sudah dikumpulkan lalu dikelola sehingga menjadi kesatuan data yang berurutan serta bermakna. Pengelolaan data bisa dilaksanakan dengan bermacammacam metode seperti metode random, klasifikasi, atau dihitung dengan metode tertentu dan diartikan seturut dengan tingat kepercayaan tertentu. Proses pengolahan data dilakukan dengan menghitung hasil percobaan yang telah dilakukan.

e. Verification (Pembuktian): peserta didik melaksanakan pengujian secara mendetail guna melakukan pembuktian atas suatu konsep yang diperoleh di awal. Verifikasi berdasarkan pada data yang sudah diolah sebelumnya. Setelah pengolahan data selanjutnya adalah pembuktian yaitu dengan melihat hasil percobaan yang telah dilakukan dan membandingkan dengan hipotesa awal yang telah disusun.

f. Generalization (Menarik Simpulan / Generalisasi): tahap generalisasi merupakan tahap pengambilan kesimpulan yang bisa dinyatakan sebagai konsep umum yang dapat digunakan unruk semua peristiwa maupun persoalan yang mirip dengan menunjukkan bukti verifikasi. Setelah mengambil kesimpulan, peserta didik wajib menjabarkan proses generalisasi yang mengutamakan pemahaman materi atas kaidah maupun konsep-konsep luas yang melandasi pengalaman individu, serta pentingnya proses pengaturan serta penarikan kesimpulan dari pengalaman terkait. Tahap selanjutnya adalah membuat kesimpulan dari hipotesa awal, percobaan yang telah dilakukan, dan verifikasi data yang telah diperoleh kemudian dijadikan suatu kesimpulan dari suatu percobaan.

Dari tahapan model pembelajaran Discovery Learning ini siswa diharuskan tidak terbatas sebagai pendengar penjelasan (ceramah) guru tetapi juga harus aktif dalam aktivitas belajar serta mampu mendorong kapabilitas berpikir kritis siswa selama pembelajaran berlangsung, sehingga dalam pembelajaran guru berperan sebagai fasilitator. Kelebihan model pembelajaran Discovery Learning ini setelah dilaksanakan dalam pembelajaran adalah membantu peserta didik untuk memperbaiki dan meningkatkan keterampilan berpikir kritis, mendorong peserta didik untuk aktif dalam pembelajaran dan mengungkapkan gagasangagasan yang dimiliki, mendorong peserta didik untuk percaya diri dalam mengungkapkan ide dan gagasan di kelas, proses pembelajaran yang berlangsung lebih menyenangkan dan ada timbal baliknya antara peserta didik dan guru, serta melatih peserta didik untuk merumuskan hipotesis dari praktik yang dilakukan. Kelemahan dari model pembelajaran ini adalah peserta didik yang kurang siap dengan pertanyaan-pertanyaan guru dan juga terdapat peserta didik yang kurang aktif maka kesusahan dalam mengimbangi teman yang lain.

Hasil riset ini serupa dengan hasil rujukan yang dilaksanakan oleh Toni Hidayat, Mawardi, Suhandi Astuti (2019: 1-9) yang menghasilkan simpulan yaitu: 1) Kemampuan berpikir kritis siswa memanfaatkan metode belajar Discovery Learning lebih efektif dibandingan metode belajar konvensional; 2) Hasil belajar murid saat aktivitas mengajar metode Discovery Learning lebih efektif disandingkan dengan metode pengajaran konvensional; 3) Ada relasi yang positif antara kapabilitas berpikir kritis dengan kenaikan hasil belajar peserta didik. Penelitian lain yang dilakukan oleh Ratih Dwi Yulianti Rahayu, Mawardi, Suhandi Astuti (2019: 8-13) dalam hasil penelitiannya menemukan bahwa model pembelajaran Discovery Learning dapat meningkatkan keterampilan berpikir kritis dan hasil belajar siswa kelas 4 SDN Karangduren 02. Kesimpulan tersebut didasari oleh pada siklus I $15 \%$ ada di golongan rendah, $63 \%$ di golongan tinggi, dan $22 \%$ di golongan sangat tinggi serta di siklus II, $37 \%$ berada di golongan tinggi dan $63 \%$ di golongan sangat tinggi. Evaluasi belajar murid di siklus I yang mencapai batas tuntas sebanyak $63 \%$ sementara $37 \%$ lainnya belum mencapai 
batas tuntas sementara di siklus II sebanyak 15\% murid belum mencapai batas tuntas sementara $85 \%$ lainnya sudah mencapai.

\section{KESIMPULAN}

Menurut hasil analisa data dari riset yang sudah dilakukan maka bisa disimpulkan bahwa model pengajaran Discovery Learning dapat mengasah keterampilan berpikir kritis siswa kelas 5 di SD Negeri Sidorejo Lor 06 Salatiga yang ditunjukkan dengan tingkat berpikir kritis siklus I 26,32\% pada kategori sangat tinggi, $31,58 \%$ pada kategori tinggi, $15,79 \%$ kategori sedang, dan 26,32\% pada kategori rendah. Kemudian pada siklus II terjadi peningkatan menjadi 42,10\% kategori sangat tinggi, 36,84\% kategori tinggi, dan 21,05\% kategori sedang. Penelitian ini menunjukkan peningkatan dan dapat terlaksana dengan baik karena dalam pembelajaran Discovery Learning dilaksanakan dengan metode-metode: a) pengaplikasian stimulasi (stimulation); b) identifikasi masalah (problem statement); c) pengumpulan informasi (data collection); d) pengolahan informasi (data processing); e) pembuktian (verification); serta f) penarikan kesimpulan (generalization).

Saran yang dapat diberikan berdasarkan riset yang sudah dilaksanakan, antara lain model pembelajaran Discovery Learning dapat digunakan guru untuk mengasah keterampilan berpikir kritis siswa. Model pembelajaran Discovery Learning ini melatih siswa untuk lebih aktif dalam proses pembelajaran sehingga pendidik tidak lagi hanya memberikan ceramah di depan kelas tetapi juga harus aktif dalam menggunakan model-model pembelajaran yang dapat mendukung keterampilan murid dan menaikkan efektivitas belajar murid.

\section{UCAPAN TERIMA KASIH}

Penulis mengucapkan terima kasih kepada semua pihak yang telah membantu kelancaran penelitian ini diantaranya kepala sekolah yang memberi ijin penelitian dan guru kelas 5 SD Negeri Sidorejo Lor 06 Salatiga serta peserta didik kelas 5 sebagai subjek penelitian atas kerja sama selama penelitian berlangsung.

\section{REFERENSI}

Anyafulude, Joy Chinelo (2013). Effects of Problem-Based and Discovery-Based Instructional on Students' Academic
Achievement in Chemistry. Asia-Pacific Forum on Science Learning and Teaching Journal of Science and Technology. 3: 151-156.

Faiz, Fahrudin (2012). Thinking Skill (Pengantar Menuju Berpikir Kritis). Yogyakarta: SUKA-Press UIN Sunan Kalijaga.

Hidayat, T., Mawardi, M., \& Astuti, S. (2019). Peningkatan Kemampuan Berpikir Kritis dan Hasil Belajar Siswa Kelas IV Melalui Model Pembelajaran Discovery Learning pada Tema Indahnya Keberagangan Negeriku. Judika: Jurnal Pendidikan Unsika, 7(1), 1-9.

Kemendikbud (2013). Modul Pelatihan Implementasi Kurikulum 2013. Badan Pengembangan Sumber Daya Manusia Pendidikan dan Kebudayaan dan Penjaminan Mutu Pendidikan, Kementerian Pendidikan dan Kebudayaan. Jakarta.

Mawardi, M. (2014). Pemberlakuan Kurikulum SD/MI Tahun 2013 dan Implikasinya Terhadap Upaya Memperbaiki Proses Pembelajaran Melalui PTK. Scholaria: Jurnal Pendidikan Dan Kebudayaan, 4(3), 107-121.

https://doi.org/10.24246/j.scholaria.2014. v4.i3.p107-121

Nurhayati, Eti (2011). Psikologi Pendidikan Inovatif. Yogyakarta: Pustaka Pelajar.

Rahayu, R.D.Y., Mawardi, M., \& Astuti, S. (2019). Peningkatan Keterampilan Berpikir Kritis dan Hasil Belajar Siswa Kelas 4 SD melalui Model Pembelajaran Discovery Learning. JPDI: Jurnal pendidikan Dasar Indonesia, 4(1), 8-13.

Rifa'i, Ahmad \& Catharina Anni (2011). Psikologi Pendidikan. Semarang: Universitas Negeri Semarang.

Trianto (2010). Model Pembelajaran Terpadu. Jakarta: Bumi Aksara.

(2011). Desain Pengembangan Pembelajaran Tematik Bagi Anak Usia Dini TK/RA \& Anak Usia Kelas Awal $S D / M I$. Jakarta: Kencana. 